\section{European coal industry Conversion plans}

Plans for commercial coal gasification plants in West Germany will be complete by December, and liquefaction plants by next autumn, the Federal Ministry for Science and Technology has announced. But because German coal is very deep and very expensive, the intention is more to take a lead in the world market for such technology, than to make much use of it in Germany. So, although the construction of 14 coal refining pilot plants costing $£ 3$ billion is under study, Research Minister Volker Hauff said last week that oil and gas derived from coal would supply only 3 per cent of Germany's oil and gas needs in 1990.

Germany was forced to develop gasification and liquefaction techniques during the Second World War to provide the country with fuel, and although the technology then became uneconomic compared with cheap Middle East oil, the industry survived through massive exports to South Africa. After a lull in the sixties, German efforts were revived by the oil price rise of 1973. The United States have since spent more on developing new approaches and principles, but Germany appears to be taking a lead with real plant. German spending on research and development of new coal technologies (including remote extraction) is high, taking the lion's share of the non-nuclear energy research programme, which in turn costs some $£ 230$ million a year including industrial participation.

In the United Kingdom, investment is nowhere near so great. British Gas has just placed the contract for one pilot gasifier, using a mix of technologies and capable of converting coal dust and lump coal, at a cost of around $£ 14$ million; but this can be set against British Gas profits of some $£ 426$ million last year alone on retailing North Sea gas. The National Coal Board (NCB) has less to spend, but has recently recommended the construction of two pilot 1 tonne per hour liquefaction plants, one using the liquid solvent extraction process and the other "super-critical gas extraction"'; the cost would be $£ 50$ million shared between the NCB, British Petroleum, and the Department of Energy.

However, according to an NCB scientist, the British technology is unique in aiming to produce nearly $100 \%$ conversion of the coal into high quality transport fuels, plus some liquid petroleum gas and synthetic natural gas. The technology could provide enough impetus to resist penetration of the British market by German or US technology, and might even provide export potential. The world market in sophisticated coal technologies is expected to reach billions of pounds a year in the 1990 s, when oil prices rise to a level which would make coal competitive.

Robert Walgate

\title{
Hunter turned hunted
}

According to the Royal Society for the Protection of Birds at least 17 young peregrine falcons were stolen from UK nests this year. With peregrines selling to falconers at up to $£ 1,500$ each, nest robbery threatens to reverse the trend towards restoration of the UK breeding population which was severely affected by organochlorine pesticides twenty years ago. Present legislation prohibits the taking but not the keeping of wild birds. But the UK government has just announced plans to legislate against keeping also; it would require all birds of prey in legal captivity to be registered and ringed.

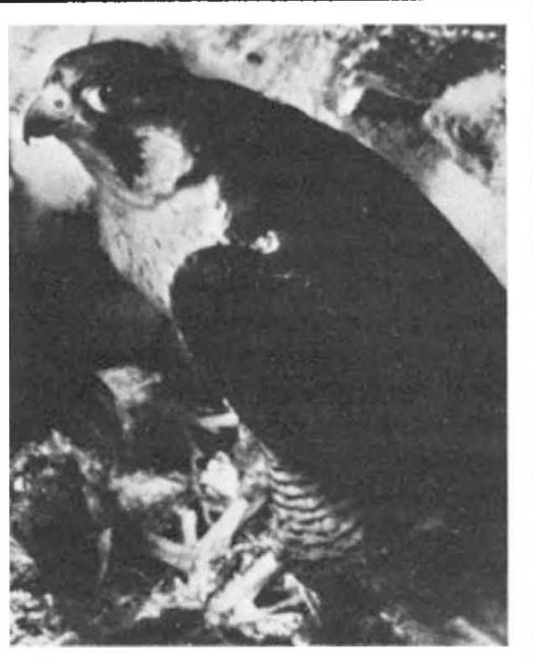

\section{Third World energy}

\section{World Bank aid}

\section{Washington}

Substantial new funds for energy research in developing countries could be one outcome of the proposals announced by the World Bank in Washington last week to help these countries meet their rapidly escalating fuel bills.

The main focus of the Bank's proposals would be the setting up of a new capital investment fund, which would raise money from private banks and lend it to Third World countries for energy projects ranging from nuclear power stations to conservation programmes.

At the same time, however, ideas for sponsoring relevant lines of research are being discussed. One possibility is that an independent fund or institute for research in renewable energy technologies could be established, perhaps taking a cue from the international group of agricultural research centres whose support the Bank currently coordinates.

In addition to the practical problems caused by energy shortages, World Bank officials have been worried that rising energy costs have made it increasingly difficult for many developing countries to pay off their international debts.

In Brazil, for example, the cost of imported petroleum rose from 12 per cent of export earnings in 1973 to 50 per cent last year; in India the increase was from 22 to 60 per cent over the same period.

The result, according to the World Development Report, 1980 published by the Bank two weeks ago, is that major oilproducing countries will run current account surpluses of about $\$ 110$ billion in 1980 , while the oil-importing, developing countries will have a combined deficit of more than $\$ 60$ billion. Efforts have been under way for some time to recycle the surpluses to ease the burden on developing countries. The political importance of this was agreed at the economic summit of western leaders in Venice in June.

The World Bank has been watching the situation closely since 1977 and has started making loans for energy projects. This year, following particularly steep price rises, the Bank's president $\mathrm{Mr}$ Robert MacNamara asked his staff for a special report on what additional steps might be taken. This report, including sections on conservation and renewable energy sources, was recently made public.

Its main proposal is that the Bank should set up a special affiliate to raise sufficient money on the private capital market to almost double the $\$ 13$ billion in loans which the Bank itself intends to make over the next five years on energy projects. This should be sufficient to seed an additional $\$ 75$ billion in bilateral loans, and concessional terms might be arranged for the poorer countries.

The Bank says that many of the projects it already finances show a high return on investment, sometimes up to 30 or 50 per cent. But in many countries difficulty in raising capital has resulted in only superficial efforts to seek oil, and therefore "not enough research and money have been put into the effort to establish whether there are smaller deposits that could make important contributions to their own energy supplies".

Reversing its earlier opinon, the Bank says that it now agrees that conservation programmes offer a substantial potential for cutting back energy needs.

The proposals will be discussed when the World Bank and the International Monetary Fund meet in Washington later this month. However, it is generally believed that Mr MacNamara already has informal commitments that at least part of the money can be raised.

The precise nature of the fund, however, is still open, and so too are details of the way in which money might be used to finance research - although according to World Bank officials one of the biggest needs is the collection and evaluation of performance data about new energy 
technologies that have already been developed.

The World Bank's report refers to the need to strengthen the national energy research programmes of developing countries, in particular their capacity to adapt developments made elsewhere. And it also says that attention should be given "to the possibility of organizing international programmes on specific renewable energy technologies".

David Dickson

\section{Meat substitutes}

\section{Fungal food}

Ranks Hovis McDougall (RHM) have received qualified approval from the UK Ministry of Agriculture Fisheries and Food (MAFF) to market, for human consumption, the somewhat processed mycelia of a Fusarium fungus. The company has now taken the decision in principle to test whether there is a sufficient market to make a commercial success of the processed mycelia, which goes by the name of mycoprotein.

A pilot plant at RHM Research in High Wycombe, Buckinghamshire, has already produced up to 100 tons per annum of the processed mycelia, sufficient to carry out extensive toxicological and nutritional tests. These have shown that mycoprotein can be fed without ill effects to generations of laboratory animals. It has also passed a number of short-term tests on human volunteers. In nutritional terms mycoprotein compares well with meat, for which it might be a substitute. On a dry weight basis it contains 45 per cent protein - with an acceptable amino acid composition and has a low fat (10-15 per cent, mostly unsaturated) and cholesterol content. There is also no doubt that it can be made palatable. The only questions now are whether or not its high fibre content (20-25 per cent) is as beneficial as current advocates of fibre would have it, and whether it will meet consumer resistance.

The fungus from which mycoprotein is produced is the A35 strain of Fusarium graminearum, a strain which has lost the pathogenicity to plants possessed by its relatives. It is grown in continuous culture at $30^{\circ} \mathrm{C}$ in 1,300 -litre tanks with glucosesyrup as the carbon source and ammonia as the source of nitrogen. A key process follows in which the mycelia are immediately heated up to $64^{\circ} \mathrm{C}$ for 20 minutes. That treatment kills the mycelia,

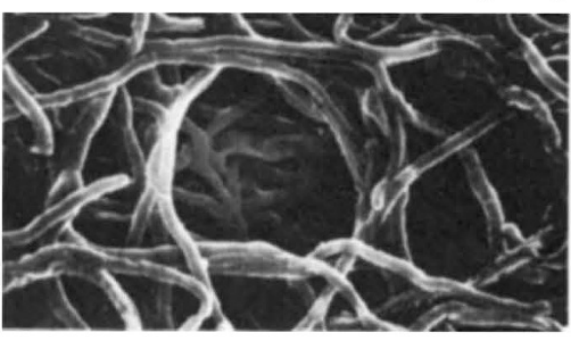

Fusarium mycelia before inactivates their proteolytic enzymes, so that there is no breakdown of protein, but allows the fungal ribonucleases to degrade nucleic acids into products which can be washed out of the cells. In that way the nucleic acid content of the mycelia is reduced from 10 per cent to below the acceptable upper limit of 1 per cent.

Furthermore the rapid heat treatment of the mycelia serves to reduce turgor with the result that mycoprotein has a texture that is not dissimilar to meat fibre. With the addition of flavouring and colouring, it can be made into a passable imitation of fish, chicken, veal or ham. Without any additions it is an unpalatable, colourless, tasteless product.

Human trials of mycoprotein have been very limited so far. Two small-scale and short-term nutritional studies have been carried out by Professor N. S. Scrimshaw at the Massachusetts Institute of Technology and some larger but less rigorous tests have been completed by RHM. The only problem that has emerged is a single case of an allergic reaction to mycoprotein which RHM claim is about par for the course.

On the basis of the human and animal tests MAFF has given permission to RHM to market mycoprotein on a limited scale once a specification has been agreed upon. It has also asked for further animal work to assess the effects of mycoprotein on mineral balance. There are two concerns in that respect. The first is that mycoprotein is lacking in the minerals, particularly iron and zinc, contained in meat. And the second is that the high fibre content of mycoprotein will lead to the retention in the intestine of dietary minerals from other sources - hence a recent recommendation that soya protein for human consumption be fortified with iron

Mycoprotein is the first of its kind. Several other microorganisms are grown and processed world-wide to provide protein supplements to animal feed, but none for human consumption. Also, as $\mathrm{Dr}$ J. Edelman, Director of Research at RHM, is at pains to point out, most of the animal feed supplements are the product of bacteria growing on hydrocarbons, and hence classifiable as single cell protein, whereas mycoprotein is produced by a multicellular fungus growing on glucose.

The main question mark still hanging over the future of mycoprotein is whether or not the public will buy it. When the project was started RHM had their eye on the protein gap that was believed to exist in

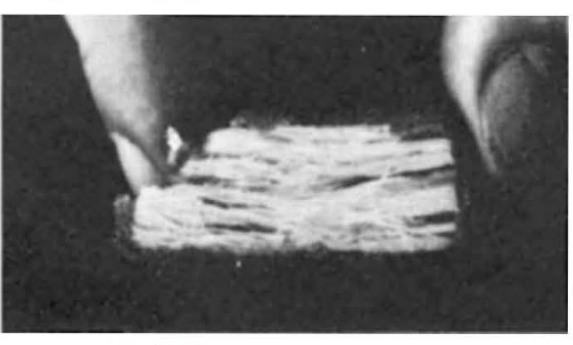

and after many developing countries. That gap has since been declared a myth. Consequently RHM now have their eye on the UK convenience-food market (plans to seek approval for sale in the US have been put on ice because of the attitude of the Food and Drug Administration). To break into that market with mycoprotein will be no easy matter. Psychological barriers to new foods may be surmountable if the price is right but mycoprotein can only be cheap if produced in large enough quantity. Ten thousand tons per annum $(0.25$ per cent of annual UK meat consumption) would be realistic for that purpose, claims $\mathrm{Dr}$ Edelman; one hundred thousand tons would be "a bonanza" for the "nylon of the food trade".

Peter Newmark

\section{Culture collections \\ Fears for fungi}

The effectiveness of Britain's main collection of non-pathogenic microfungi could be seriously reduced from March next year if $£ 20,000$ annual support cannot be found in the meantime. The collection is currently funded to the tune of approximately $£ 60,000$ per annum by the Commonwealth Mycological Institute (CMI), which houses it, and $£ 20,000$ by the Natural Environment Research Council (NERC), which has said that it will cease to pay its share early next year.

Similar problems were experienced earlier this year by the National Collection of Yeast Cultures (see Nature, 24 January), as a result of which an inter-Research Council committee was set up with the aim of observing and monitoring the maintenance of culture collections. The problems of the microfungi collection are the first to be investigated by the new committee. Next week, members of the committee will visit the CMI to make detailed recommendations on how the collection should be continued and whether alternative funds are needed. It will then start looking for new sources of money.

The difficulties with both the yeast and microfungi collections have arisen because they have never been permanently funded. NERC took over the bill for the microfungi collection ten years ago from the then Ministry of Trade and Industry on a temporary basis. The grant was designed to rise with inflation up to a ceiling of $£ 20,000$, a level that was reached several years ago. According to the curator of the microfungi collection, Dr Agnes Onions, the collection is already run on a shoestring and if the NERC funds are not replaced it will be impossible to fulfull all the functions of a national collection.

The collection is the main source of nonpathogenic microfungi in Britain for industry, research and educational establishments.

Judy Redfearn 